"There is nothing like an eyewitness account to heat up historical events. ... A fascinating, fast-paced read. . . the personal storyabout one man's failure to build a better world, about a stranger's futile efforts to be accepted by a distrustful culture, about dreams proved false and nightmares come true-is riveting."

-Nick Gallo, Seattle Weekly

"A gripping story about an idealistic young American who freely cast his lot with the Chinese revolution only to be struck down by that revolution at the floodtide of its success.... One lives with him through inhuman cruelty and the mindless horror of sixteen years of solitary confinement."-Leonard Woodcock, first American Ambassador to China

"The Man Who Stayed Bebind hooked me from start to finish. These are rare, tragic, sometimes startling insights into Mao's China at its self-destructive worst. Whether you sympathize with Sidney Rittenberg or not (and there will be times when you have doubts) he was there as history was made and unmade, and became part of its scar tissue. His prison portrait of Madame Mao as the shrieking harridan of the Red Terror will stay with me a long time. And his own personal story is an amazing tale in its own right." - Sterling Seagrave, author of The Soong Dynasty

"An extraordinary and revealing account of how someone was swept into the Chinese Communist movement and stayed with it through its many blunders, excesses, and cruelties. . . A fascinating autobiography-honest, moving, chilling, and quite illuminating." -Dr. Michel Oksenberg, former National Security Council Aide on China Policy

"For more than a decade, I have been recording Chinese stories of hope, imprisonment, and disillusion. Nowhere is that story told more poignantly, honestly, or compellingly than in this book. ... [It] is fascinating, excruciatingly honest, painful to read, and destined to be a classic in the literature of gods that have failed." -Anne F. Thurston, Boston Globe 
"The gripping saga of an expatriate whose extraordinary experiences left him without illusions about Marxism - but with his personal ideals triumphantly intact."-Kirkus Reviews

"Sidney Rittenberg has had one of the most remarkable lives of anyone I have ever met. The story of his life is not only a fascinating and valuable witness to one of the greatest historical upheavals of [the twentieth] century, but is a vivid testimony to the power of good in the midst of evil."-Billy Graham

"Rittenberg lived a strange life, but he is not a stranger. Seen from the inside, his 'life of perks, privilege, and deluded complicity' makes sense. In the ultimate test of good autobiography, we see with a shock how it could have been us."-Andrew J. Nathan, Washington Post

"I found The Man Who Stayed Bebind hard to put down. No American has ever merged as fully, hopefully — and disastrously - with Communist China as Rittenberg did for four decades from the 1940s. The book is lively, poignant, and revealing. Rittenberg offers a window on Beijing politics that anyone seriously interested in China's recent past and likely future should read."--Ross Terrill, author of China in Our Time

"In a class by itself. ... This story is off the wall, amazing, unbelievably funny and sad.... What I want to know is: Where are the miniseries people?"-Carolyn See, Los Angeles Times 
The Man Who Stayed Bebind 
Foreword by

Mike Wallace

Introduction by

Michael Hunt 


\section{The Man}

Who

Stayed

Behind

Sidney Rittenberg, Sr.

and Amanda Bennett

Duke University Press

Durham \& London 
(C) 2001 Duke University Press

All rights reserved Printed in the United States of America

on acid-free paper $\infty$ Library of Congress Cataloging-in-Publication

Data appear on the last printed page of this book. 
for Yulin 
